\title{
The Immunology of Autoimmune Thyroid Disease in Pregnancy
}

\author{
Francis Balucan and Terry F. Davies \\ Mount Sinai School of Medicine and the James J. Peters VA Medical Center, New York, New York, USA
}

\begin{abstract}
In pregnancy, complex physiologic changes in the immune system alters the environment for the "non-self" fetus allowing it to be tolerated in the maternal womb, while the immune system is still able to counteract external pathogens. The interplay of the immune system and the physiologic changes induced by pregnancy on the thyroid induce changes in the natural history of the autoimmune thyroid diseases (AITD). This review discusses the various players in creating this milieu, including the MHC, the T- and B-cells, sex steroids and the possible role of microchimerism. The participants provide a variety of mechanisms that create the clinical scenarios that we see in patients with AITD - most commonly the improvement in Grave's Disease during pregnancy and the rebound in thyroid autoantibodies and recurrence, or new onset, of Graves' and Hashimoto's diseases in the post-partum.
\end{abstract}

Keywords: immunology, autoimmune thyroid disease, pregnancy

\section{Introduction}

Pregnancy is a state that induces significant changes in the immune system. It is an immunotolerogenic state, allowing a semi-allogeneic fetus to exist within an environment that must still allow maternal detection and destruction of pathogens. This paradox is unique and necessary since a state of systemic immunosuppression would be disadvantageous to both the fetus and the mother. ${ }^{1}$ Pregnancy itself has a complex relationship with the normal thyroid, and with thyroid disease, and pregnancy complicating the course of autoimmune thyroid disease is a common clinical problem. ${ }^{2}$ However, the converse is also true with autoimmune thyroid disease increasing a variety of risks associated with pregnancy and its association with recurrent miscarriages. ${ }^{3}$

\section{The thyroid in pregnancy}

The thyroid undergoes transformation during pregnancy (Table 1). The thyroid gland itself may enlarge under the stimulation of hCG and the increased demand for thyroid hormones. Pregnancy is a hypervolemic state, a greater water volume increases body weight and body mass index, both of which increase thyroid volume and enlarge the distribution space for thyroid hormones. ${ }^{4}$ There is a rise in urinary excretion of iodide owing to an increased glomerular filtration rate which has to be corrected by increased dietary intake. ${ }^{5}$ All of this results in increased thyroid activity and a variable degree of TSH suppression. Thyroid binding globulin (TBG) production is increased in the pregnant liver, and its half-life prolonged because of estrogen-induced changes in sialylation resulting in increased TBG levels. Many of these physiological changes associated with pregnancy are an adaptation to improve thyroxine delivery to fetal cells, particularly neuronal cells. ${ }^{6}$

\begin{tabular}{|c|c|c|}
\hline Physical Changes & Change & Comments \\
\hline Size & Increased & $\begin{array}{l}\text { Increased in size in iodine- } \\
\text { deficient areas,but less } \\
\text { change in iodine replete } \\
\text { areas. }\end{array}$ \\
\hline $\begin{array}{l}\text { Intrathyroidal blood } \\
\text { volume } \\
\text { Biochemical Changes }\end{array}$ & Increased & \\
\hline $\begin{array}{l}\text { Thyroid binding } \\
\text { globulin }\end{array}$ & Increased & Associated with estrogen \\
\hline TSH & Decreased & Stimulation by hCG \\
\hline lodide availability & Decreased & $\begin{array}{l}\text { Creatinine clearance } \\
\text { increased }\end{array}$ \\
\hline
\end{tabular}

\section{Thyroid disease and pregnancy risks}

As mentioned earlier, the normal physiologic changes of pregnancy may result in a subsequent decrease in TSH levels during many early normal pregnancies. Such a normal state is referred to as "gestational thyrotoxicosis." However, the greater influence of a pathologically overactive or underactive thyroid gland should not be underestimated. Thyroid hormones change several aspects of reproduction directly through their impact on sex hormone binding globulin, prolactin and $\mathrm{GnRH}$ secretion. ${ }^{7}$ The interplay of thyroid hormones, autoimmunity, and the physiologic changes of pregnancy significantly influences the risks of pregnancy: ranging from early pregnancy losses to the development of infertility (Table 2). Hence, many pregnancy risks are increased by an overactive or underactive thyroid gland regardless of immune changes ${ }^{8}$ (Table 3 ).
ISSN 0857-1074

Printed in the Philippines

Copyright (C) 2012 by the JAFES

Received April 12, 2012. Accepted April 12, 2012.
Corresponding author: Francis Balucan, $M D$

Address: clo GME Office, Room 7-A11, James J Peters VA Medical Center,

130 West Kingsbridge Rd, Bronx, New York, NY 10468

E-mail address:f.balucan@gmail.com 
Table 2. Interplay of thyroid hormones on pregnancy outcomes. Hypothyroidism and hyperthyroidism may have an effect on infertility indirectly, through its interaction with menstrual dysfunction. Adapted from ${ }^{87}$, 7,8889

\begin{tabular}{|c|c|c|c|}
\hline & Miscarriage & Infertility & Comments \\
\hline Hypothyroidism & $\begin{array}{l}\text { Increased } \\
\text { risk }\end{array}$ & $\begin{array}{l}\text { Increased } \\
\text { risk }\end{array}$ & $\begin{array}{l}\text { May affect other } \\
\text { factors like } \\
\text { ovulation and } \\
\text { menstrual } \\
\text { dysfunction }\end{array}$ \\
\hline Hyperthyroidism & $\begin{array}{l}\text { Increased } \\
\text { risk }\end{array}$ & $\begin{array}{l}\text { Increased } \\
\text { risk }\end{array}$ & $\begin{array}{l}\text { May affect other } \\
\text { factors like } \\
\text { ovulation and } \\
\text { menstrual } \\
\text { dysfunction }\end{array}$ \\
\hline $\begin{array}{l}\text { Thyroid Antibody } \\
\text { Positive }\end{array}$ & $\begin{array}{l}\text { Increased } \\
\text { risk }\end{array}$ & & \\
\hline
\end{tabular}

Table 3. Maternal and fetal complications associated with thyroid dysfunction in pregnancy. Adapted from
90

\begin{tabular}{|c|c|c|}
\hline & Hypothyroidism & Hyperthyroidism \\
\hline \multirow{4}{*}{$\begin{array}{l}\text { Maternal } \\
\text { Complications }\end{array}$} & Anemia & Heart Failure \\
\hline & $\begin{array}{l}\text { Gestation-Induced } \\
\text { Hypertension and Pre- } \\
\text { Eclampsia }\end{array}$ & Pre-Eclampsia \\
\hline & Placental Abruption & $\begin{array}{l}\text { Gestational Diabetes } \\
\text { Mellitus }\end{array}$ \\
\hline & $\begin{array}{l}\text { Post-Partum } \\
\text { Hemorrhage } \\
\text { Increased Placental } \\
\text { Weight } \\
\text { Increasd Frequency of } \\
\text { Caesarean Section }\end{array}$ & \\
\hline \multirow{7}{*}{$\begin{array}{l}\text { Fetal } \\
\text { Complications }\end{array}$} & Early Fetal Loss & Neontal Mortality \\
\hline & Cretinism & $\begin{array}{l}\text { Intrauterine Growth } \\
\text { Restriction }\end{array}$ \\
\hline & Preterm Delivery & Preterm Delivery \\
\hline & Stillbirths/Perinatal Death & Still Births \\
\hline & Low Birth Weight & Low Birth Weight \\
\hline & Fetal Distress in Labor & \\
\hline & Spontaneous Abortion & \\
\hline
\end{tabular}

\section{Thyroid disease and infertility}

Infertility is defined as the absolute inability to conceive after approximately 1 year of regular intercourse without contraception. ${ }^{9}$ A pooled review of the multiple studies involving autoimmune thyroid disease (AITD) in women with infertility compared to controls showed an overall relative risk of $2.1(\mathrm{P}<0.0001) .{ }^{7}$ Infertility may be due to the hormonal changes associated with AITD or to problems with implantation of the embryo ${ }^{10}$ reflected more clearly in established pregnancies by early miscarriages (see below). It remains unclear whether AITD is simply a marker for an autoimmune imbalance in such patients or reflective of subtle thyroid hormone changes. Of interest, AITD may also occur in patients with endometriosis which is a frequent association with infertility. ${ }^{11}$ Endometriosis has also been associated with immunological changes-including endometrial autoantibodies ${ }^{11}$ and deposition of complement, cytotoxic effects on the endometrium, and contradictory declining levels, or functional defects in natural killer (NK) cells have all been reported. ${ }^{12}$ Such NK cell dysregulation may activate Graves' disease or Hashimoto's thyroiditis. ${ }^{13}$

\section{Autoimmune thyroid disease (AITD)}

The autoimmune thyroid diseases include Graves' disease, Graves' orbitopathy (opthalmopathy), Hashimoto's thyroiditis and the post partum thyroid syndromes. While the immune response is very different in these diseases (Table 4) they each are considered to be caused by the combination of an environmental insult and a genetic predisposition (Table 5). Some of these insults have been well described but they can be ascribed to only a small proportion of patients and much still needs to be learned about the causality of AITD.

\section{The effect of pregnancy on autoimmune disease}

With the physiological changes of pregnancy changing the immunologic milieu of the woman, many autoimmune diseases show differing responses owing, perhaps, to differences in their pathophysiology. ${ }^{14}$ For rheumatoid arthritis, recent studies show a modest reduction in symptoms; with less swelling of joints, less pain and morning stiffness and improved functionality in pregnancy. ${ }^{15}$ Ankylosing spondylitis seems to be unaffected --- neither improved ${ }^{16}$ nor aggravated ${ }^{17}$ with pregnancy. In systemic lupus erythematosus, many prospective studies have shown increased flare rates in pregnancy rather than improvement, although the flares in pregnancy are not as severe. ${ }^{14}$ For autoimmune thyroid disease, it is clear that Graves' disease improves during pregnancy but sometimes flare again in the post-partum. ${ }^{2}$

Table 4. A comparison between the autoimmune thyroid diseases. Adapted from ${ }^{93}$

\begin{tabular}{|c|c|c|c|}
\hline & Grave's Disease & Hashimoto's Disease & Postpartum Thyroiditis \\
\hline Incidence Rates & 99/100,000/yr (F) & $498.4 / 100,000 / y r(F)$ & $7.50 / 100$ \\
\hline Thyroid Examination & Enlarged, and soft & Enlarged and firm & Variable \\
\hline Pathological Findings & Hyperplasia & Follicular atrophy & Paucity of follicular atrophy \\
\hline Lymphocyte Infiltration & Patchy & Diffuse with B-cell germinal centers. & Patchy \\
\hline Timeframe & Permanent & Permanent & Transient \\
\hline Primary Immune Defect & Antibodies to the TSH-R & Cytotoxic T-cells & Cytotoxic T-cells \\
\hline Extrathyroid Manifestations & $\begin{array}{l}\text { Yes } \\
\text { Graves Ophthalmopathy } \\
\text { pretibial myxedema }\end{array}$ & Rare & No \\
\hline Environmental factors involved & $\begin{array}{l}\text { lodine Excess } \\
\text { Smoking } \\
\text { Stress } \\
\text { Yersinia enteroliticainfection } \\
\text { Radiation } \\
\text { Drugs: Amiodarone, Interferon-y }\end{array}$ & $\begin{array}{l}\text { Selenium Deficiency } \\
\text { Stress } \\
\text { Drugs: Amiodarone, Interferon-y }\end{array}$ & \\
\hline
\end{tabular}


As far as Hashimoto's thyroiditis is concerned, while there is suggestive evidence of deterioration during pregnancy, the main clinical event is post-partum thyroiditis which can be considered new onset, but is usually transient Hashimoto's thyroiditis. ${ }^{18}$ However, established Hashimoto's thyroiditis may deteriorate in the post partum as evidenced by a need for increased thyroxine intake. ${ }^{19}$

\begin{tabular}{|c|c|c|c|}
\hline $\begin{array}{c}\text { Gene } \\
\text { Symbol }\end{array}$ & Gene Name & $\begin{array}{c}\text { Chromosome } \\
\text { Location }\end{array}$ & $\begin{array}{l}\text { Odds } \\
\text { Ratio }\end{array}$ \\
\hline$H L A$ & Major histocompatibility complex & $6 \mathrm{p} 21$ & $2.0-4.0$ \\
\hline CTLA4 & $\begin{array}{l}\text { Cytotoxic T-lymphocyte- } \\
\text { associated protein } 4\end{array}$ & $2 q 33$ & $1.5-2.2$ \\
\hline PTPN22 & $\begin{array}{l}\text { Protein tyrosine } \\
\text { phosphatase, non- } \\
\text { receptor type } 22 \\
\text { (lymphoid) }\end{array}$ & $1 \mathrm{p} 13$ & $1.4-1.9$ \\
\hline$C D 40$ & $\begin{array}{l}\text { CD40 molecule, TNF } \\
\text { receptor superfamily } \\
\text { member } 5\end{array}$ & $20 q 11$ & $1.3-1.8$ \\
\hline $\begin{array}{l}\text { IL2RA } \\
\text { (CD25) }\end{array}$ & Interleukin 2 receptor, alpha & $10 p 15$ & $1.1-1.4$ \\
\hline FCRL3 & Fc receptor-like 3 & $1 q 23$ & $1.1-1.3$ \\
\hline$T G$ & Thyroglobulin & $8 q 24$ & $1.3-1.6$ \\
\hline TSHR & $\begin{array}{l}\text { Thyroid-stimulating } \\
\text { hormone receptor }\end{array}$ & $14 q 31$ & $1.4-2.6$ \\
\hline
\end{tabular}

\section{The immunotolerogenic state of pregnancy}

The paradoxical immunotolerogenic state of pregnancy was explained by Medawar using three hypotheses: a) the anatomic separation of the fetus from the mother, b) the antigenic immaturity of the fetus, and c) the indolence or inertness of the mother. ${ }^{20}$ Although newer studies have challenged these hypotheses it is now clear that each of these factors may have a role in creating this environment.

\section{The MHC}

MHC molecules are polymorphic cell surface proteins that bind with antigenic peptides. They are widely expressed, especially in inflammatory areas typical of autoimmune disease. ${ }^{21}$ Their role includes the presentation of such peptides to the immune system via antigen-specific $\mathrm{T}$ cells. These proteins are divided into MHC class I and MHC class II molecules interacting with CD8+ and CD4+ cells respectively. In humans they are referred to as human leukocyte antigens (HLA) and are derived from a highly complex gene region on chromosome $6 .^{22}$ All auto-immune diseases have shown a genetic association with the HLA gene locus as manifested by the prevalence of certain HLA alleles in the patient populations. ${ }^{23}$ For example, Graves' disease has been widely associated with HLA-DR3 in Caucasians and further investigation has suggested that it is residue 74 (Arginine) in the molecule which is the major influence. ${ }^{24}$

The feto-maternal interface, which includes the villous trophoblasts and syncytiotrophoblast microparticles, avoid allogeneic responses because they lack HLA class I and class II proteins and only express other MHC molecules such as HLA-S, -E, -F and HLA-G. ${ }^{25}$ In fact, extravillous trophoblasts migrate from tips of placental villi into maternal decidual tissue where they appear to promote immune regulation and spiral artery modeling. ${ }^{25}$ HLA-G expression can also be found on thymic epithelial cells, the cornea, and the nasal matrix which are also considered to be immunologically privileged sites. It can be induced in other cell types during pathologic processes including cancer, inflammatory disorders, infections and allotransplantation and is thought to confer resistance to NK cells. ${ }^{26}$

\section{T Lymphocytes}

T-cells play an important role in the immune response in pregnancy. T-helper cells are classically divided into Th1 cells, characterized by IL-2, and IFN- $\gamma$ production involved in cellular immunity and Th2 cells which are characterized by the production of IL-4, IL- 5 and IL-13 which are involved in humoral immunity (Figure 2).22 Although studies of CD4+ $\mathrm{T}$ Cells in pregnancy have shown very modest changes in absolute numbers, ${ }^{27}$ the Th1/Th2 ratio has been proposed to indicate a successful pregnancy as a Th2 phenomenon, with the Th2 chemokines downregulating the Th1 response. ${ }^{28}$ Hence the Th1/Th2 ratio is low in pregnancy but remains particularly high in the proliferative endometrium. ${ }^{29}$ The variation in the ratio of these cells has been used to explain the various phenotypes of autoimmune diseases in relation to pregnancy. For example, multiple retrospective and cohort studies have shown that cell-mediated autoimmune diseases improve during pregnancy, and worsen in the post-partum. ${ }^{30}$ However, this Th1/Th2 dichotomy is not able to explain the multitude of immune responses in pregnancy, among them the fact that some Th1 cytokines are necessary in some aspects of pregnancy 31 Furthermore, although the Th2 predominance suggested an explanation for the exacerbation of humoral autoimmune diseases in pregnancy such as lupus ${ }^{32}$ it does not explain the suppression of autoantibodies, including thyroid autoantibodies (Figure 1), seen in many autoimmune diseases and as exemplified by the improvement of Graves' disease in pregnancy. ${ }^{2} \quad$ Newer studies have shown a multitude of T-cells that share a common lineage with the Th1 and Th2 (Figure 2) cells and which helps explain the complex interplay of immune responses in pregnancy as described below.

\section{Regulatory T Cells}

A third subset of CD4+ $\mathrm{T}$ cells (Tregs) have been implicated in the regulation of tolerance and have helped explain some of the problems with the Th1/Th2 ratio hypothesis. It is important to note that two particular subsets of regulatory cells occur, the CD4+CD25+FoxP3+ cells that are thymus-generated and termed, natural $\mathrm{T}$ regulatory cells (nTreg), while a second subset of Treg cells can be induced by antigens presented in a tolerogenic form. ${ }^{33,34}$ A schematic is shown in Figure 3. 


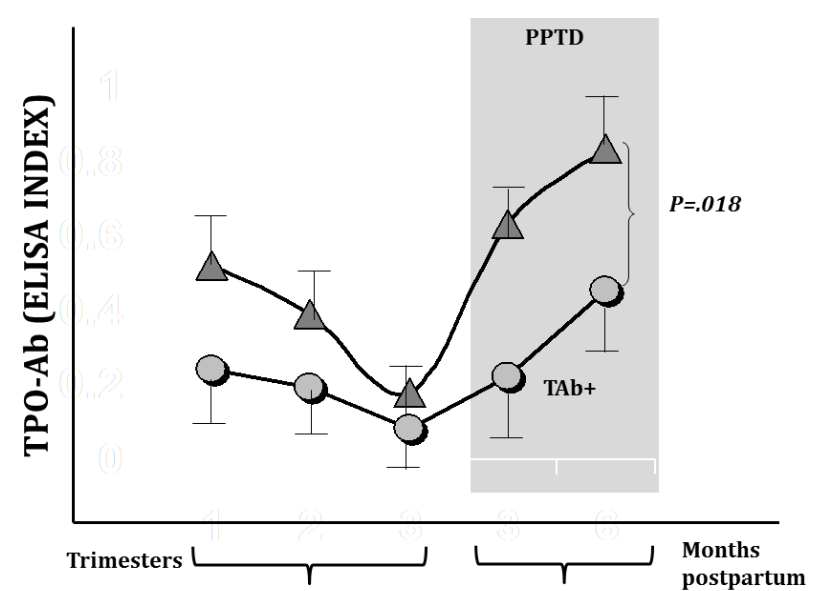

Figure 1. Thyroid autoantibodies in pregnancy. There is a modulation of TPO autoantibodies in pregnancy, but this rebounds postpartum, characterized clinically as Postpartum Thyroiditis (PPTD). Adapted from ${ }^{56}$

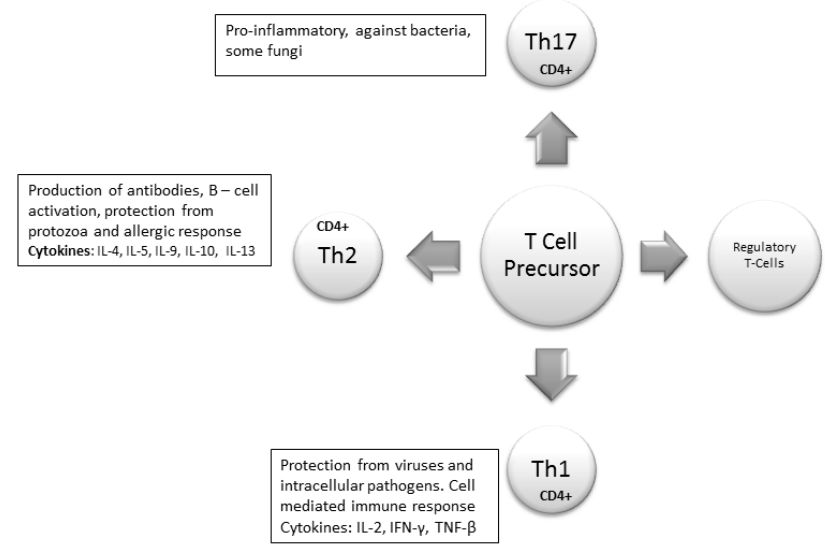

Figure 2. The common lineage of CD4+ T-Cells. This simplified model shows the common lineage of the various T-cells, including the helper cells, CD4+ Th1, Th2, Th17, which are implicated in immunity, and the regulatory T-cells. A balance of these cells and their cytokines are essential in maintenance of pregnancy. References: ${ }^{39} 97$

We now know that the CD4+CD25+FoxP3+ regulatory $\mathrm{T}$ cells are the most potent and widespread lineage of immune cells that are capable of regulating immune function. ${ }^{35}$ They have major protective functions in autoimmune disease, transplantation tolerance, gastrointestinal homeostasis and inflammatory disease. The role of induced T-regulatory cells is unclear; speculation exists whether they may have a role in bystander suppression. Bystander suppression is the modulation of effector T-cells that are specific to a particular antigen, if it arises in the same antigen presenting cell, or target cell, or is within the vicinity. ${ }^{34}$

The mechanism of action of how Treg cells are able to regulate immune tolerance is still being defined, but they appear capable of suppressing proliferation and cytokine production in both the CD4+ and CD8+ T cell lineages, and are also able to inhibit B-cell proliferation and immunoglobulin production. The Treg cells are also able to inhibit the maturation and function of antigen presenting cells. Of direct relevance to our discussion, Treg cells may proliferate peripherally after encountering foreign antigens (such as fetal antigens), and migrate towards the feto-maternal interface generating a tolerant environment characterized by cytokines such as TGF- $\beta$, Leukemia Inhibitory Factor (LIF), and Hemoxygenase 1 (HO-1) which are proposed to protect pregnancy. ${ }^{36}$ The hemooxygenases break down heme into bilirubin and $\mathrm{CO}$, stopping the increase in toxic free heme. ${ }^{37}$ Hence, increases in Treg cells during pregnancy have been well documented and clearly are major contributors to the dampening of autoimmune responses in pregnancy. It is also likely that deficiency in their function or proliferative responsiveness may endanger pregnancy. ${ }^{38}$

\section{Th17 cells}

Th-17 cells are a unique effector subset that share the same lineage with Th1 and Th2 and which have recently been recognized to have an important role in immune regulation, immune pathogenesis and host defense. ${ }^{39}$ In normal pregnant women, the values of IL-17 are present throughout the whole pregnancy, although higher during the third trimester. ${ }^{40}$ In-vitro studies have shown that IL-17 increases the invasive potential of choriocarcinoma cells. ${ }^{41,42}$ The studies reflect a potential role of these cytokines in implantation and placentation. Additionally, IL-17 increases progesterone secretion, ${ }^{43}$ which is needed in pregnancy maintenance.

With regard to autoimmunity, enhanced IL-17 expression has been seen in various autoimmune diseases such as rheumatoid arthritis, psoriasis and multiple sclerosis. ${ }^{44}$ Its role in autoimmunity has been theorized from increased levels of IL-17 found in an acute renal rejection model ${ }^{45}$, and neutralization of IL-17 prevented acute rejection of aortic and cardiac allografts. ${ }^{46}$ However, its role in the immunotolerogenic pregnancy is unclear. Some studies have shown increased Th17 cells in the blood and decidua in unexplained recurrent spontaneous abortion patients, ${ }^{47}$ while the levels of circulating and decidual Th17 cells in healthy pregnancy are stable. ${ }^{48}$

\section{B Cells}

B cells are not only capable of antibody secretion but are also potent antigen presenting cells interacting with the $\mathrm{T}$ cell receptors. ${ }^{22}$ However, there appear to be no significant changes in the quantity of B-cells in the circulation during normal human pregnancy yet one unifying characteristic is the fall in autoantibody titers (Figure 1). As discussed earlier, this is most likely secondary to the increase in Treg cells. However, estrogen has also been shown to deliver a negative signal towards $B$ cell function in pregnancy, ${ }^{49}$ and this effect is lost in the postpartum period. Newly described B regulatory cells 


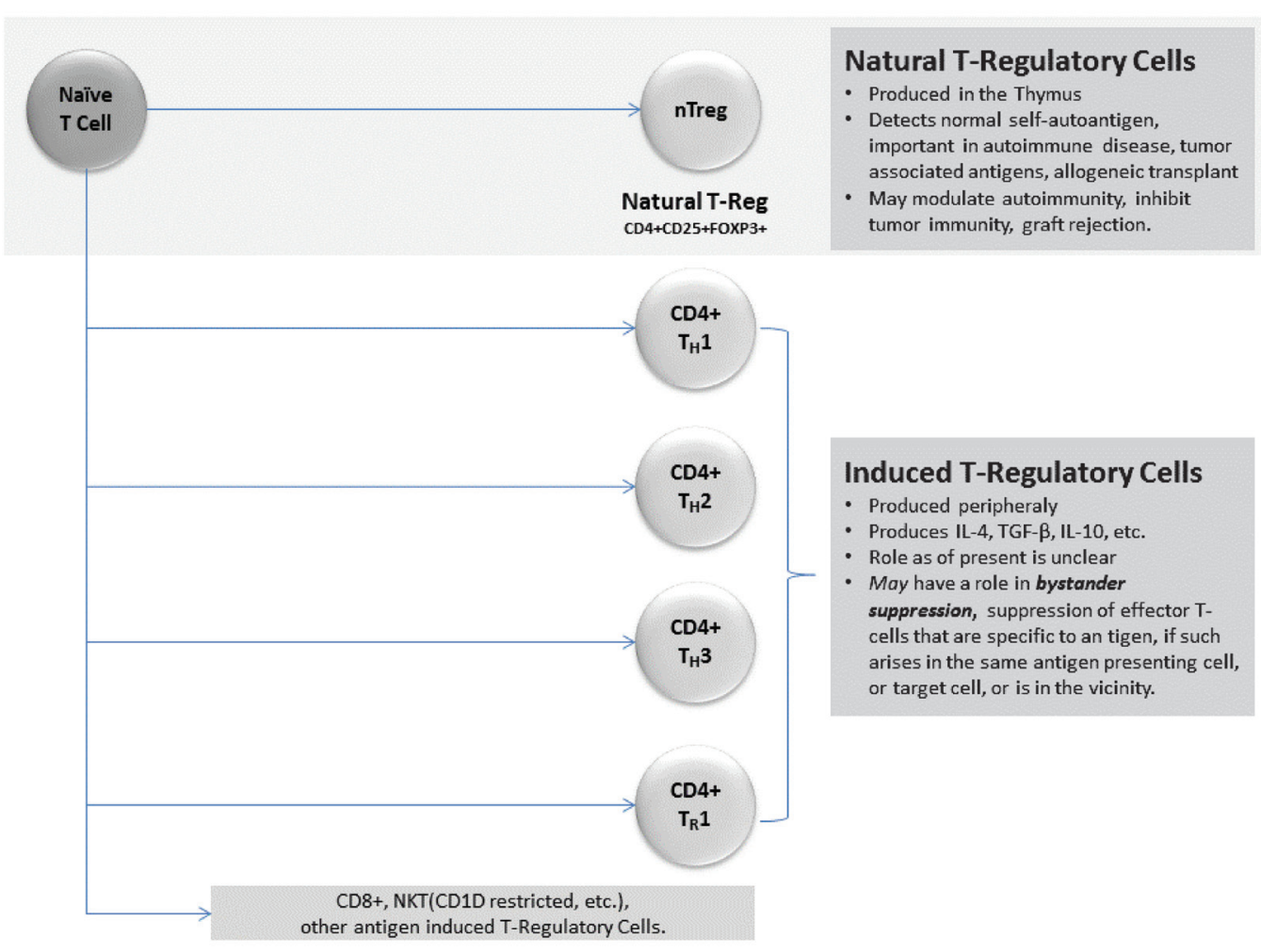

Figure 3. The regulatory T-Cells. This schematic of the regulatory T-cells shows two subsets occurring from a naïve Tcell, the natural T-regulatory cells, and the Induced T-Regulatory cells. Both may have a role in immunosuppression, but the exact mechanism is still being elucidated. Based on : ${ }^{34}$

have also been shown to modulate immune response and inflammation ${ }^{50}$ but their role in pregnancy still remains to be elucidated.

\section{Thyroid autoantibodies}

Grave's Disease and Hashimoto's Thyroiditis differ in clinical presentation but have commonalities in some of their immunological characteristics (Table 4). ${ }^{51}$ This similarity includes lymphocytic infiltration of the thyroid and autoantibodies against various thyroid antigens, including thyroid peroxidase (TPO) and thyroglobulin (Tg) and perhaps also pendrin, ${ }^{52}$ and the $\mathrm{Na}+/ \mathrm{I}-$ cotransporter ${ }^{53}$. However, the major autoantibodies in Hashimoto's Thyroiditis are the antithyroid peroxidase antibodies (TPOAb) and antithyroglobulin antibodies $(\mathrm{Tg} \mathrm{Ab}) .{ }^{54}$ In pregnancy, as mentioned earlier there is a marked fall in both TPOAb and TgAb levels, and both increase 6 months postpartum. ${ }^{55,56}$

\section{TSH receptor antibodies}

Stimulation of the TSH receptor (TSHR) by autoantibodies is the primary immunopathogenesis of Grave's disease (Table 4). Stimulating TSHR antibodies interact with conformational epitopes in the TSH receptor ectodomain, and consequently initiate TSH signaling 57 (Figure 4). Early studies demonstrated a decrease in the levels of TSHR anitbodies in pregnancy, with the lowest point in the third trimester, and a rising trend again in the post partum. ${ }^{58-60}$ Patients may also develop blocking TSHR antibodies which have been reported to cause neonatal hypothyroidism $^{61}$ and/or neutral TSHR antibodies which may contribute to the persistence of the disease by their apoptotic action on thyroid cells which acts as an immune stimulant. ${ }^{57}$
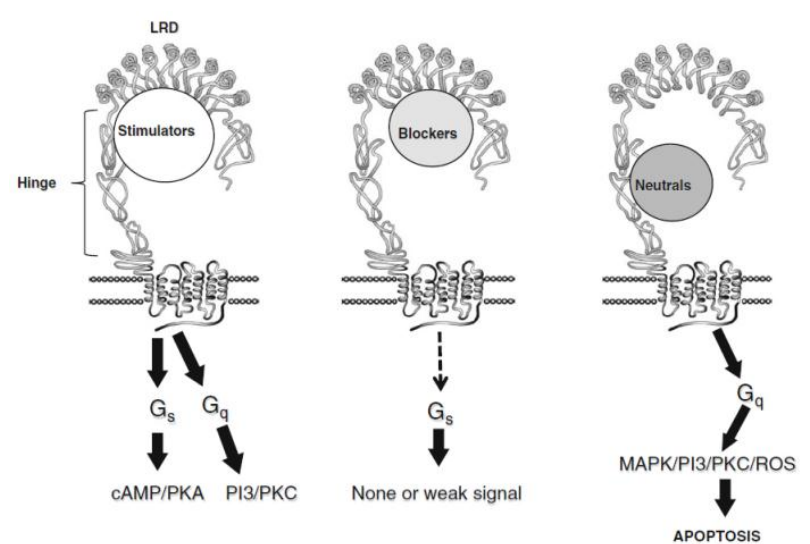

Figure 4. Varieties of TSH Receptor antibodies and their different functions. From reference: ${ }^{57}$

\section{Other immune cells}

The role of NK cells involves cell lysis and cytokine production directed against virally infected cells and tumor cells. Interferon (IFN- $\gamma$ ) is one of the key products which restrict viral infection. The number of peripheral NK cells is only moderately decreased in pregnant women compared with non pregnant women while the expression of HLA G at the feto-maternal interface suggests they have 
an integral role in pregnancy. ${ }^{27}$ Dendritic cells have a major role in the adaptive immune response, and literature notes the pro-activating effects of estrogen on dendritic cells, while progesterone has an inhibitory function. ${ }^{62}$ In pregnancy, the decidual dendritic cells can modulate the TH1/Th2 cytokine balance in promotion of pregnancy. ${ }^{63}$

\section{Microchimerism}

Microchimerism is the presence of a low-level of foreign cells or their progeny in an individual ${ }^{64}$ which may have the potential to initiate an autoimmune response (Figure 5 ). Usually this occurs only in women after pregnancy although it may also occur after receiving a transplant or transfusion; bidirectional cell trafficking between twins in utero has also been demonstrated. ${ }^{64}$ Paternally-derived DNA has been seen in post-partum females up to 27 years later. ${ }^{65}$ The potential role of microchimerism in autoimmune disease arose from the identification of fetal cells as male DNA in inflammatory skin lesions and peripheral blood of patients with scleroderma ${ }^{66}$, primary biliary cirrhosis, systemic lupus erythematous and Sjogren's syndrome. In the thyroid gland, fetal cells have been identified in patients with nodules, Hashimoto's thyroiditis and Graves' disease. ${ }^{67}$ A mouse model has demonstrated the targeting of the thyroid gland by fetal cells which were primarily immune and dendritic cells. ${ }^{68}$ It is possible, therefore, that such foreign cells initiate an immune response within their targets by activating bystander cells (Figure 5). Evidence for a role for microchimerism has also come from identical twins of different sexes who are more likely to demonstrate thyroid autoantibodies than identical twins of the same sex. ${ }^{69}$ Although some studies have not shown that parity is a risk factor for autoimmune thyroid disease ${ }^{70}$ other investigators have observed this phenomenon thus supporting the microchimerism hypothesis. ${ }^{71}$

\section{The role of sex hormones in immunity}

The difference in the prevalence of most autoimmune diseases between male and females and the major immune changes in pregnancy have led to the belief that sex steroids must have effects on both the innate and adaptive immune system. ${ }^{72}$ For example, women are 7 times more likely to develop autoimmune thyroid disease than men. One explanation is that testosterone has been implicated in apoptosis of T-cells. ${ }^{73}$ Although the absolute number of lymphocytes from either gender is the same, the percentage of $\mathrm{T}$ lymphocytes is lower in men. ${ }^{74}$ On the other hand, estrogen reduces bone marrow stroma, generating a faster development time for B lymphocytes, and additionally stimulating extra-marrow lymphopoiesis, that may be pro-autoimmune as the cells may avoid the deletion process during development. ${ }^{75}$ Women have greater baseline plasma levels of $\operatorname{IgG}$ and $\operatorname{IgM} .^{76}$ Estrogen enhances activation-induced deaminase (AID) which deaminates cytokines at immunoglobulin loci initiating somatic hypermutation. ${ }^{77}$ NK cells' cytotoxic action is greater in postmenopausal women and in men than in women of reproductive age, suggesting a possible role for progesterone or estradiol. ${ }^{78}$ Another set of immune effector cells, dendritic cells are sentinels that recognize pathogens throughout the whole body. Evidence exists that estrogen can activate dendritic cells, while progesterone inhibits their actions. ${ }^{62}$

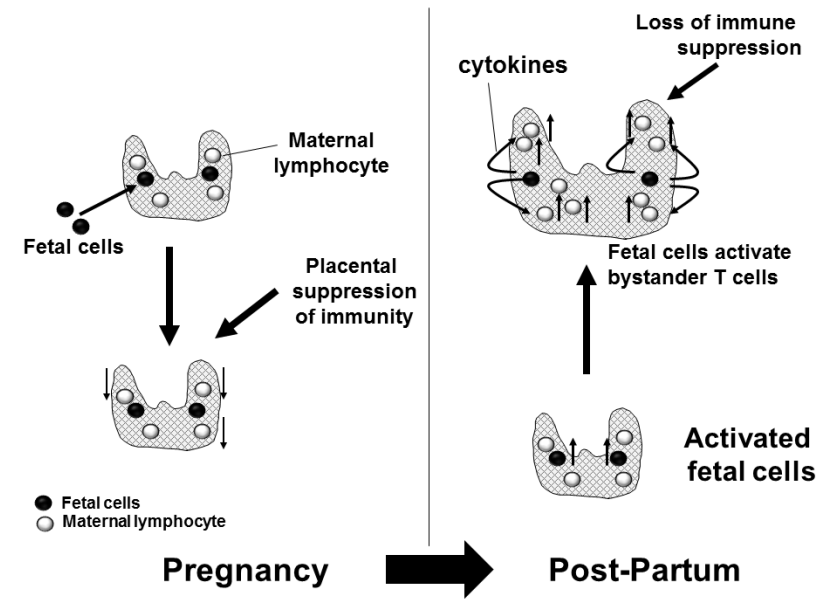

Figure 5. Hypothetical mechanism of how fetal cells modulate autoimmune thyroid disease post-partum. Through the immunotolerogenic pregnancy, fetal microchimerism is established in the Thyroid tissue, although the exact mechanism of how fetal immune cells migrate to the thyroid is still unknown. The immune suppression allows minimal interaction between the maternal and immune cells. Post-partum, partial sustained immunuspression effects allow the survicval of fetal cells, however the loss of placental immune suppression activates intrathyroidal fetal immune cells. The consequent activation of the fetal cells allow a graft $v s$ host reaction against the maternal antigens, through immunomodulatory cytokines. This activates intrathyroidal maternal autoreactive $T$ cells, eventually initiating and/or exacerbating AITD. ${ }^{68}$

\section{Miscarriage and pre-term birth}

The studies of Stagnaro-Green ${ }^{56}$ in New York and confirmed by Glinoer ${ }^{79}$ in Belgium and in multiple subsequent studies, have demonstrated increases in the miscarriage rate in women who are thyroid autoantibody positive and such women are also more likely to deliver early. ${ }^{80}$ A meta-analysis ascertaining this relationship showed an odds ratio (OR) of 2.73 (95\% CI 2.20-3.40) in eight case control and ten longitudinal studies. ${ }^{81} \mathrm{~A}$ number of etiologies have been hypothesized as the cause of the relationship between spontaneous termination of pregnancy and autoimmune thyroid antibodies (Table 6).

\footnotetext{
Table 6: Possible causes of increased miscarriages in thyroid autoantibody positive women. Adapted from 84

1 The existence of a subtle degree of hypothyroidism

2 There is an autoimmune "imbalance" in the female merely reflected bythyroid autoantibodies.

3 Thyroid autoantibodies may act directly on the placenta or the fertilized ovum causing the rejection.

4 Women with thyroid autoimmunity and subfertility may become pregnant at an older age with increased risk
} 
In patients who have evidence of AITD, prospective studies have characterized the onset of hypothyroidism in pregnancy, although euthyroid to start with and despite a reduction in antibody titers thus suggesting the association may be secondary to subtle thyroid deficiency. ${ }^{82}$ Furthermore, subclinical hypothyroidism per se, with its increased levels of TSH has been shown to be related to increased early pregnancy loss when compared to euthyroid patients, or thyroid autoimmune patient's without thyroid hormonal imbalance. ${ }^{80}$ This may reflect the reduced capacity of the thyroid with pregnancy's increased demands. ${ }^{83}$ These hypotheses have been extrapolated to interventional studies with levothyroxine, showing a decrease in miscarriage rates in patients with AITD treated with levothyroxine compared to placebo. ${ }^{84}$ Such studies await confirmation before being clinically applicable but the concept that thyroid antibodies are merely markers for subtle immune abnormalities remains.

\section{Conclusions}

Pregnancy is a state of immunotolerance with the ability to continuously ward off pathogens. The unique milieu in pregnancy allows us to examine the various roles of different immune-effector cells in generating this paradoxical immune-tolerant state from changes in thyroid function. Extrapolating the information to autoimmune thyroid disease helps explain many of the clinical situations we meet and should potentially improve our management of these common disorders.

\section{References}

1. Munoz-Suano A, Hamilton AB, Betz AG. Gimme shelter: The immune system during pregnancy. Immunological Reviews 2011;241:20-38.

2. Amino N, Tanizawa O, Mori H, et al. Aggravation of thyrotoxicosis in early pregnancy and after delivery in Graves' disease. Journal of Clinical Endocrinology and Metabolism 1982;55:108-12.

3. Stagnaro-Green A, Glinoer D. Thyroid autoimmunity and the risk of miscarriage. Best Pract Res Clin Endocrinol Metab 2004;18:167-81.

4. Gaberscek S, Zaletel K. Thyroid physiology and autoimmunity in pregnancy and after delivery. Expert Review of Clinical Immunology 2011;7:697-706; quiz 7.

5. Glinoer D. The regulation of thyroid function in pregnancy: Pathways of endocrine adaptation from physiology to pathology. Endocrine Reviews 1997;18:404-33.

6. Lazarus JH. Thyroid function in pregnancy. British Medical Bulletin 2011;97:137-48.

7. Poppe K, Velkeniers B, Glinoer D. Thyroid disease and female reproduction. Clinical Endocrinology 2007;66:309-21.

8. Negro R, Mestman JH. Thyroid disease in pregnancy. Best Pract Res Clin Endocrinol Metab 2011;25:927-43.

9. Poppe K, Velkeniers B, Glinoer D. The role of thyroid autoimmunity in fertility and pregnancy. Nature Clinical Practice Endocrinology \& Metabolism 2008;4:394-405.

10. Grassi G, Balsamo A, Ansaldi C, Balbo A, Massobrio M, Benedetto C. Thyroid autoimmunity and infertility. Gynecological Endocrinology 2001;15:389-96.

11. Eisenberg VH, Zolti M, Soriano D. Is there an association between autoimmunity and endometriosis? Autoimmunity Reviews 2012.

12. Matarese G, De Placido G, Nikas Y, Alviggi C. Pathogenesis of endometriosis: Natural immunity dysfunction or autoimmune disease? Trends in Molecular Medicine 2003;9:223-8.

13. Konova E. The role of NK cells in the autoimmune thyroid diseaseassociated pregnancy loss. Clinical Reviews in Allergy \& Immunology 2010;39:176-84.
14. Ostensen M, Villiger PM, Forger F. Interaction of pregnancy and autoimmune rheumatic disease. Autoimmunity Reviews 2011.

15. de Man YA, Dolhain RJ, van de Geijn FE, Willemsen SP, Hazes JM. Disease activity of rheumatoid arthritis during pregnancy: Results from a nationwide prospective study. Arthritis and Rheumatism 2008;59:1241-8.

16. Husby G, Ostensen M, Gran JT. Ankylosing spondylitis and pregnancy. Clinical and Experimental Rheumatology 1988;6:165-7.

17. Lui NL, Haroon N, Carty A, et al. Effect of pregnancy on ankylosing spondylitis: A case-control study. The Journal of Rheumatology 2011;38:2442-4.

18. Amino N, Tada H, Hidaka Y. Postpartum autoimmune thyroid syndrome: A model of aggravation of autoimmune disease. Thyroid : official journal of the American Thyroid Association 1999;9:705-13.

19. Galofre JC, Haber RS, Mitchell AA, Pessah R, Davies TF. Increased postpartum thyroxine replacement in Hashimoto's thyroiditis. Thyroid 2010;20:901-8.

20. Billington WD. The immunological problem of pregnancy: 50 years with the hope of progress. A tribute to Peter Medawar. J Reprod Immunol 2003;60:1-11.

21. Pujol-Borrell R, Soldevila G, Buscema M, et al. Inappropriate expression of HLA class II molecules in endocrine epithelial cells: the phenomenon, the new experimental data and comparison with animal models. Journal of Autoimmunity 1989;2 Suppl:163-9.

22. Levinson W. Review of medical microbiology and immunology. 11th ed. New York: McGraw-Hill Medical; 2010.

23. Shiina T, Inoko H, Kulski JK. An update of the HLA genomic region, locus information and disease associations: 2004. Tissue Antigens 2004;64:631-49.

24. Ban Y, Davies TF, Greenberg DA, et al. Arginine at position 74 of the HLA-DR beta1 chain is associated with Graves' disease. Genes and immunity 2004;5:203-8.

25. Tilburgs T, Scherjon SA, Claas FH. Major histocompatibility complex (MHC)-mediated immune regulation of decidual leukocytes at the fetal-maternal interface. J Reprod Immunol 2010;85:58-62.

26. Favier B, LeMaoult J, Rouas-Freiss N, Moreau P, Menier C, Carosella ED. Research on HLA-G: An update. Tissue Antigens 2007;69:207-11.

27. Kuhnert M, Strohmeier R, Stegmuller M, Halberstadt E. Changes in lymphocyte subsets during normal pregnancy. European Journal of Obstetrics, Gynecology, and Reproductive Biology 1998;76:147-51.

28. Wegmann TG, Lin H, Guilbert L, Mosmann TR. Bidirectional cytokine interactions in the maternal-fetal relationship: Is successful pregnancy a TH2 phenomenon? Immunol Today 1993;14:353-6.

29. Saito S, Tsukaguchi N, Hasegawa T, Michimata T, Tsuda H, Narita N. Distribution of Th1, Th2, and Th0 and the Th1/Th2 cell ratios in human peripheral and endometrial $\mathrm{T}$ cells. American Journal of Reproductive Immunology 1999;42:240-5.

30. Golding A, Haque UJ, Giles JT. Rheumatoid arthritis and reproduction. Rheum Dis Clin North Am 2007;33:319-43, vi-vii.

31. Chaouat G. The Th1/Th2 paradigm: Still important in pregnancy? Semin Immunopathol 2007;29:95-113.

32. Ruiz-Irastorza G, Lima F, Alves J, et al. Increased rate of lupus flare during pregnancy and the puerperium: Aprospective study of 78 pregnancies. Br J Rheumatol 1996;35:133-8.

33. Shevach EM. From vanilla to 28 flavors: Multiple varieties of $\mathrm{T}$ regulatory cells. Immunity 2006;25:195-201.

34. von Herrath MG, Harrison LC. Antigen-induced regulatory T cells in autoimmunity. Nat Rev Immunol 2003;3:223-32.

35. Guerin LR, Prins JR, Robertson SA. Regulatory T-cells and immune tolerance in pregnancy: A new target for infertility treatment? Human Reproduction Update 2009;15:517-35.

36. Leber A, Teles A, Zenclussen AC. Regulatory T cells and their role in pregnancy. American Journal of Reproductive Immunology 2010;63:445-59.

37. Zenclussen AC, Lim E, Knoeller S, et al. Heme oxygenases in pregnancy II: HO-2 is downregulated in human pathologic pregnancies. American Journal of Reproductive Immunology 2003;50:66-76.

38. Saito S, Shima T, Nakashima A, Shiozaki A, Ito M, Sasaki Y. What is the role of regulatory $\mathrm{T}$ cells in the success of implantation and early pregnancy? Journal of Assisted Reproduction and Genetics 2007;24:379-86.

39. Weaver CT, Harrington LE, Mangan PR, Gavrieli M, Murphy KM. Th17: An effector CD4 $\mathrm{T}$ cell lineage with regulatory $\mathrm{T}$ cell ties. Immunity 2006;24:677-88. 
40. Martinez-Garcia EA, Chavez-Robles B, Sanchez-Hernandez PE, et al. IL-17 increased in the third trimester in healthy women with term labor. American Journal of Reproductive Immunology 2011;65:99-103.

41. Pongcharoen S, Niumsup P, Sanguansermsri D, Supalap K, Butkhamchot $\mathrm{P}$. The effect of interleukin-17 on the proliferation and invasion of JEG-3 human choriocarcinoma cells. American Journal of Reproductive Immunology 2006;55:291-300.

42. Saito S, Nakashima A, Ito M, Shima T. Clinical implication of recent advances in our understanding of IL-17 and reproductive immunology. Expert Review of Clinical immunology 2011;7:649-57.

43. Pongcharoen S, Supalap K. Interleukin-17 increased progesterone secretion by JEG-3 human choriocarcinoma cells. American Journal of Reproductive Immunology 2009;61:261-4.

44. Steinman L. A brief history of $\mathrm{T}(\mathrm{H}) 17$, the first major revision in the $\mathrm{T}(\mathrm{H}) 1 / \mathrm{T}(\mathrm{H}) 2$ hypothesis of $\mathrm{T}$ cell-mediated tissue damage. Nature Medicine 2007;13:139-45.

45. Loong CC, Hsieh HG, Lui WY, Chen A, Lin CY. Evidence for the early involvement of interleukin 17 in human and experimental renal allograft rejection. Journal of Pathology 2002;197:322-32.

46. Li J, Simeoni E, Fleury S, et al. Gene transfer of soluble interleukin-17 receptor prolongs cardiac allograft survival in a rat model. European Journal of Cardio-thoracic surgery 2006;29:779-83.

47. Wang WJ, Hao CF, Yi L, et al. Increased prevalence of $\mathrm{T}$ helper 17 (Th17) cells in peripheral blood and decidua in unexplained recurrent spontaneous abortion patients. J Reprod Immunol 2010;84:164-70.

48. Nakashima A, Ito M, Yoneda S, Shiozaki A, Hidaka T, Saito S. Circulating and decidual Th17 cell levels in healthy pregnancy. American Journal of Reproductive Immunology 2010;63:104-9.

49. Kincade PW, Medina KL, Smithson G, Scott DC. Pregnancy: A clue to normal regulation of B lymphopoiesis. Immunol Today 1994;15:53944

50. Bouaziz JD, Yanaba K, Tedder TF. Regulatory B cells as inhibitors of immune responses and inflammation. Immunological Reviews 2008;224:201-14.

51. Weetman AP. Determinants of autoimmune thyroid disease. Nature Immunology 2001;2:769-70.

52. Yoshida A, Hisatome I, Taniguchi S, et al. Pendrin is a novel autoantigen recognized by patients with autoimmune thyroid diseases. Journal of Clinical Endocrinology and Metabolism 2009;94:442-8.

53. Raspe E, Costagliola S, Ruf J, Mariotti S, Dumont JE, Ludgate M. Identification of the thyroid $\mathrm{Na}+\mathrm{I}-$ cotransporter as a potential autoantigen in thyroid autoimmune disease. European Journal of Endocrinology/European Federation of Endocrine Societies 1995;132:399-405.

54. Salvatore DD, T., Schlumberger, M., Hay, I., Larsen, P. . Thyroid. In: Melmed SP, K. Larsen, P. Kronenberg, H., ed. Williams Endocrinology. 12th ed. Philadelphia, PA: Elsevier; 2011:327-50.

55. Feldt-Rasmussen U, Hoier-Madsen M, Rasmussen NG, Hegedus L, Hornnes P. Anti-thyroid peroxidase antibodies during pregnancy and postpartum. Relation to postpartum thyroiditis. Autoimmunity 1990;6:211-4

56. Stagnaro-Green A, Roman SH, Cobin RH, el-Harazy E, AlvarezMarfany M, Davies TF. Detection of at-risk pregnancy by means of highly sensitive assays for thyroid autoantibodies. JAMA 1990;264:1422-5.

57. Morshed SA, Latif R, Davies TF. Delineating the autoimmune mechanisms in Graves' disease. Immunologic research 2012.Ahead of Print. DOI: 10.1007/s12026-012-8312-8

58. Zakarija M, McKenzie JM. Pregnancy-associated changes in the thyroid-stimulating antibody of Graves' disease and the relationship to neonatal hyperthyroidism. Journal of Clinical Endocrinology and Metabolism 1983;57:1036-40.

59. Parker RH, Beierwaltes WH. Thyroid antibodies during pregnancy and in the newborn. Journal of Clinical Endocrinology and Metabolism 1961;21:792-8.

60. Stagnaro-Green A, Roman SH, Cobin RH, el-Harazy E, Wallenstein S, Davies TF. A prospective study of lymphocyte-initiated immunosuppression in normal pregnancy: Evidence of a T-cell etiology for postpartum thyroid dysfunction. Journal of Clinical Endocrinology and Metabolism 1992;74:645-53.

61. McKenzie JM, Zakarija M. Fetal and neonatal hyperthyroidism and hypothyroidism due to maternal TSH receptor antibodies. Thyroid 1992;2:155-9.
62. Hughes GC, Clark EA. Regulation of dendritic cells by female sex steroids:Relevance to immunity and autoimmunity. Autoimmunity 2007;40:470-81.

63. Blois SM, Kammerer U, Alba Soto C, et al. Dendritic cells: Key to fetal tolerance? Biology of Reproduction 2007;77:590-8.

64. Sarkar K, Miller FW. Possible roles and determinants of microchimerism in autoimmune and other disorders. Autoimmunity Reviews 2004;3:454-63.

65. Bianchi DW, Zickwolf GK, Weil GJ, Sylvester S, DeMaria MA. Male fetal progenitor cells persist in maternal blood for as long as 27 years postpartum. Proceedings of the National Academy of Sciences of the United States of America 1996;93:705-8.

66. Nelson JL, Furst DE, Maloney S, et al. Microchimerism and HLAcompatible relationships of pregnancy in scleroderma. Lancet 1998;351:559-62.

67. Ando T, Imaizumi M, Graves PN, Unger P, Davies TF. Intrathyroidal fetal microchimerism in Graves' disease. Journal of Clinical Endocrinology and Metabolism 2002;87:3315-20.

68. Ando T, Davies TF. Clinical Review 160: Postpartum autoimmune thyroid disease:The potential role of fetal microchimerism. Journal of Clinical Endocrinology and Metabolism 2003;88:2965-71.

69. Brix TH, Hansen PS, Kyvik KO, Hegedus L. Aggregation of thyroid autoantibodies in twins from opposite-sex pairs suggests that microchimerism may play a role in the early stages of thyroid autoimmunity. Journal of Clinical Endocrinology and Metabolism 2009;94:4439-43.

70. Walsh JP, Bremner AP, Bulsara MK, et al. Parity and the risk of autoimmune thyroid disease: A community-based study. Journal of Clinical Endocrinology and Metabolism 2005;90:5309-12.

71. Friedrich N, Schwarz S, Thonack J, John U, Wallaschofski H, Volzke $\mathrm{H}$. Association between parity and autoimmune thyroiditis in a general female population. Autoimmunity 2008;41:174-80.

72. Gonzalez DA, Diaz BB, Rodriguez Perez Mdel C, Hernandez AG, Chico BN, de Leon AC. Sex hormones and autoimmunity. Immunology Letters 2010;133:6-13.

73. Huber SA, Kupperman J, Newell MK. Estradiol prevents and testosterone promotes Fas-dependent apoptosis in CD4+ Th2 cells by altering Bcl 2 expression. Lupus 1999;8:384-7.

74. Bouman A, Schipper M, Heineman MJ, Faas MM. Gender difference in the non-specific and specific immune response in humans. American Journal of Reproductive Immunology 2004;52:19-26.

75. Grimaldi CM, Cleary J, Dagtas AS, Moussai D, Diamond B. Estrogen alters thresholds for B cell apoptosis and activation. Journal of Clinical Investigation 2002;109:1625-33.

76. Giltay EJ, Fonk JC, von Blomberg BM, Drexhage HA, Schalkwijk C, Gooren LJ. In vivo effects of sex steroids on lymphocyte responsiveness and immunoglobulin levels in humans. Journal of Clinical Endocrinology and Metabolism 2000;85:1648-57.

77. Pauklin S, Sernandez IV, Bachmann G, Ramiro AR, Petersen-Mahrt SK. Estrogen directly activates AID transcription and function. Journal of Experimental Medicine 2009;206:99-111.

78. Yovel G, Shakhar K, Ben-Eliyahu S. The effects of sex, menstrual cycle, and oral contraceptives on the number and activity of natural killer cells. Gynecologic Oncology 2001;81:254-62.

79. Glinoer D, Soto MF, Bourdoux P, et al. Pregnancy in patients with mild thyroid abnormalities: Maternal and neonatal repercussions. Journal of Clinical Endocrinology and Metabolism 1991;73:421-7.

80. De Vivo A, Mancuso A, Giacobbe A, et al. Thyroid function in women found to have early pregnancy loss. Thyroid : 2010;20:633-7.

81. Prummel MF, Wiersinga WM. Thyroid autoimmunity and miscarriage. European Journal of Endocrinology / European Federation of Endocrine Societies 2004;150:751-5.

82. Glinoer D, Riahi M, Grun JP, Kinthaert J. Risk of subclinical hypothyroidism in pregnant women with asymptomatic autoimmune thyroid disorders. Journal of Clinical Endocrinology and Metabolism 1994;79:197-204.

83. Ohara N, Tsujino $\mathrm{T}$, Maruo $\mathrm{T}$. The role of thyroid hormone in trophoblast function, early pregnancy maintenance, and fetal neurodevelopment. Journal of Obstetrics and Gynaecology Canada: 2004;26:982-90.

84. Negro R, Formoso G, Mangieri T, Pezzarossa A, Dazzi D, Hassan H. Levothyroxine treatment in euthyroid pregnant women with autoimmune thyroid disease: effects on obstetrical complications. Journal of Clinical Endocrinology and Metabolism 2006;91:2587-91. 
85. Berghout A, Wiersinga W. Thyroid size and thyroid function during pregnancy: an analysis. European Journal of Endocrinology / European Federation of Endocrine Societies 1998;138:536-42.

86. Fister P, Gaberscek S, Zaletel K, Krhin B, Gersak K, Hojker S. Thyroid volume and intrathyroidal blood flow increase during pregnancy. Clinical Endocrinology 2006;65:828-9.

87. LaFranchi SH, Haddow JE, Hollowell JG. Is thyroid inadequacy during gestation a risk factor for adverse pregnancy and developmental outcomes? Thyroid 2005;15:60-71.

88. Anselmo J, Cao D, Karrison T, Weiss RE, Refetoff S. Fetal loss associated with excess thyroid hormone exposure. JAMA.2004;292:691-5.

89. Poppe K, Glinoer D. Thyroid autoimmunity and hypothyroidism before and during pregnancy. Human Reproduction Update 2003;9:149-61.

90. Krassas GE, Poppe K, Glinoer D. Thyroid function and human reproductive health. Endocrine Reviews 2010;31:702-55.

91. Stagnaro-Green A. Overt hyperthyroidism and hypothyroidism during pregnancy. Clinical Obstetrics and Gynecology 2011;54:478-87.

92. Luewan S, Chakkabut $\mathrm{P}$, Tongsong $\mathrm{T}$. Outcomes of pregnancy complicated with hyperthyroidism: A cohort study. Archives of Gynecology and Obstetrics 2011;283:243-7.

93. McGrogan A, Seaman HE, Wright JW, de Vries CS. The incidence of autoimmune thyroid disease: a systematic review of the literature. Clinical Endocrinology 2008;69:687-96.

94. Prummel MF, Strieder T, Wiersinga WM. The environment and autoimmune thyroid diseases. European Journal of Endocrinology / European Federation of Endocrine Societies 2004;150:605-18.

95. Stagnaro-Green A. Postpartum thyroiditis. Best Pract Res Clin Endocrinol Metab 2004;18:303-16.

96. Muller AF, Drexhage HA, Berghout A. Postpartum thyroiditis and autoimmune thyroiditis in women of childbearing age: Recent insights and consequences for antenatal and postnatal care. Endocrine Reviews 2001;22:605-30.

97. Zhu J, Paul WE. CD4 T cells: Fates, functions, and faults. Blood 2008;112:1557-69.

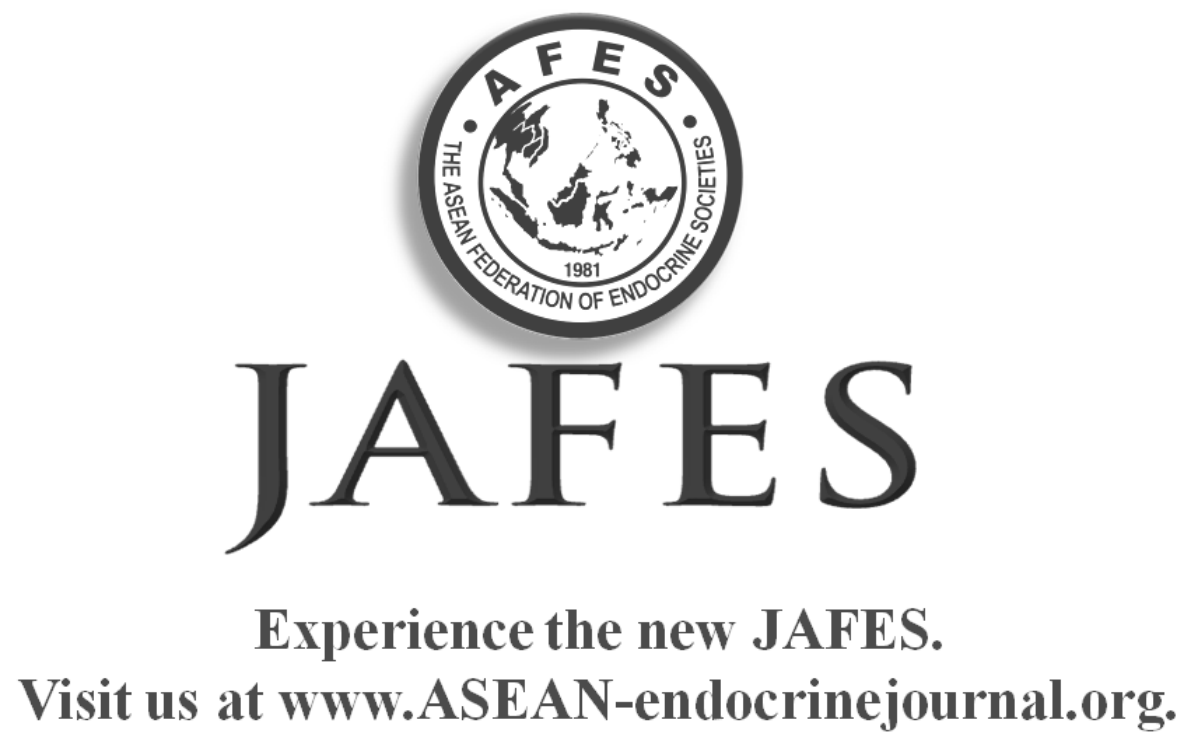

